\title{
Assessing the operation rules of a reservoir system based on a detailed modelling chain
}

\author{
M. Bruwier, S. Erpicum, M. Pirotton, P. Archambeau, and B. J. Dewals \\ University of Liege (ULG), Hydraulics in Environmental and Civil Engineering (HECE), Liege, Belgium \\ Correspondence to: M. Bruwier (mbruwier@ulg.ac.be)
}

Received: 3 July 2014 - Published in Nat. Hazards Earth Syst. Sci. Discuss.: 9 September 2014

Revised: 4 February 2015 - Accepted: 6 February 2015 - Published: 2 March 2015

\begin{abstract}
According to available climate change scenarios for Belgium, drier summers and wetter winters are expected. In this study, we focus on two multi-purpose reservoirs located in the Vesdre catchment, which is part of the Meuse basin. The current operation rules of the reservoirs are first analysed. Next, the impacts of two climate change scenarios are assessed and enhanced operation rules are proposed to mitigate these impacts. For this purpose, an integrated model of the catchment was used. It includes a hydrological model, one-dimensional and two-dimensional hydraulic models of the river and its main tributaries, a model of the reservoir system and a flood damage model. Five performance indicators of the reservoir system have been defined, reflecting its ability to provide sufficient drinking water, to control floods, to produce hydropower and to reduce low-flow conditions. As shown by the results, enhanced operation rules may improve the drinking water potential and the low-flow augmentation while the existing operation rules are efficient for flood control and for hydropower production.
\end{abstract}

\section{Introduction}

Large reservoirs are particularly effective in mitigating hydrological extremes such as floods and low-flows. For instance, preventive turbines operation may prove efficient for flood control. Optimal reservoir management has been analysed in a number of studies, focusing either on large dams (Bieri and Schleiss, 2013; Fortin et al., 2007; Payne et al., 2004), on smaller structures (Camnasio and Becciu, 2011) or even on run-of-river schemes enabling in-stream storage (Heller et al., 2010).
The number of different water uses considered in these studies was generally limited to two or three aspects, such as hydropower and floods (Bieri and Schleiss, 2013; Jordan et al., 2012), hydropower and minimum environmental flow or energy production, low-flow augmentation and flood support for agricultural purposes (Bader et al., 2003). In contrast, Fortin et al. (2007) performed a combined analysis of the reservoir system performances in terms of flood control, leisure activities, hydropower and ecology. Similarly, a particularly holistic approach was followed by Heller et al. (2010), who considered not only hydropower and flood control, but also groundwater issues, leisure infrastructures as well as ecological and economic criteria. However, their study is restricted to a purely qualitative assessment. Optimal reservoir management was also studied from a Control Theory perspective, addressing the methodological challenges resulting from the strong non-linearities in the system response and the associated high uncertainties (Castelletti et al., 2008).

A broad range of measures may contribute to mitigate the effects of global climate change on water resources and on flood risk (e.g. Poussin et al., 2012). In particular, authors such as Payne et al. (2004) and Fortin et al. (2007) analysed the potential for enhanced reservoir management to act as an efficient option for mitigating hydrological impacts of climate change. Based on different downscaling techniques, they accounted for climate change projections for the time periods 2010-2039, 2040-2069 and 2070-2098. As shown by their results, climate change tends to increase competition between different water uses; but adaptation of the reservoir management can make a substantial difference by contributing to reach more acceptable new trade-offs between the competing water uses. 


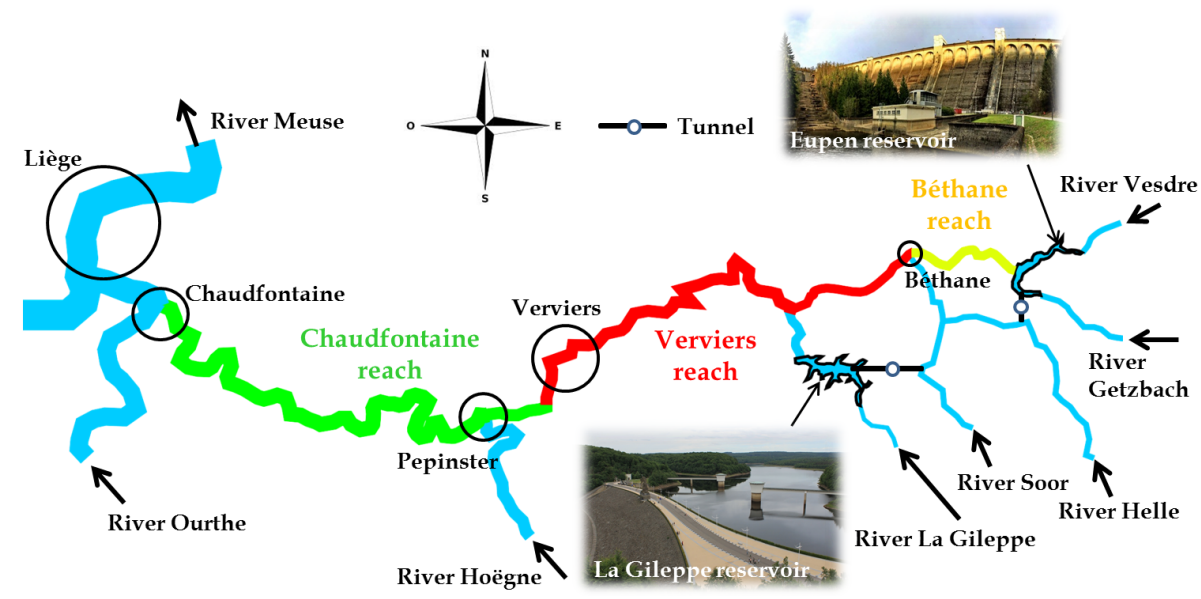

Figure 1. Vesdre valley from upstream of the Eupen reservoir to the mouth into the River Ourthe, which flows into the River Meuse.

Other types of scenarios considered in previous studies include growing water demand for irrigation (Bader et al., 2003) or the upgrade of the reservoir system by dam heightening (Bieri and Schleiss, 2013; Bieri et al., 2011).

In this paper, we focus on a system of two large multipurpose reservoirs in the Vesdre catchment (Belgium), which is located in the basin of the River Meuse.

Based on the complex management rules applied by the dam operator, the existing operation policy of the reservoirs was first analysed for the period 1974-2004, and a sensitivity analysis was conducted for the main parameters involved in these operation rules. Next, two extreme climate change scenarios were investigated by introducing spatially distributed perturbations in the time series of temperature and rainfall in the catchment. These scenarios correspond respectively to possible "wet" and "dry" future climates and they are available for time horizons up to 2050 and 2100. Finally, the feasibility of mitigating the impacts of climate change on the reservoir system performance was appreciated by testing modifications in the reservoir management plan.

Four aspects were considered to assess the performance of the reservoir system as well as its evolution as a function of climate change and adapted reservoir management: guarantee of drinking water availability, flood control, low-flow augmentation and hydropower production.

The analysis relies on a comprehensive integrated modelling of the catchment. A process-oriented and spatially distributed hydrological model was applied to estimate hourly water yields to the reservoirs and along the whole course of the rivers. It was forced with temperature and precipitation data from 1961 to 2005. One-dimensional (1-D) hydraulic modelling was used to model the flow in the rivers. Climate change scenarios were incorporated in the analysis by means of a tailored perturbation tool for downscaling effects of climate evolution in Belgium (Ntegeka et al., 2014). Next, using a detailed two-dimensional (2-D) hydraulic model, inunda- tion modelling was performed for a number of characteristic flood discharges deduced from flood frequency analysis. Finally, flood risk curves were derived from economic flood damage estimates obtained by combining the results of inundation modelling with land cover and land-use data.

\section{Case study}

The study focuses on the catchment of the River Vesdre, which covers $700 \mathrm{~km}^{2}$. From its spring in the High Fens, the River Vesdre flows for $70 \mathrm{~km}$, in a relatively narrow and deep valley into the River Ourthe, which is the main tributary of the River Meuse in Belgium (Fig. 1). The mean annual discharge in Chaudfontaine, near the mouth, is about $11 \mathrm{~m}^{3} \mathrm{~s}^{-1}$. Two $50 \mathrm{~m}$ high dams are located in the upper part of the catchment: Eupen dam and La Gileppe dam. The former is situated on the main course of the River Vesdre, $3 \mathrm{~km}$ upstream of the town Eupen, while the latter is on the left-bank tributary La Gileppe. Both reservoirs have approximately the same storage capacity equal to $25 \mathrm{hm}^{3}$. However, the subcatchment of Eupen reservoir (10000 ha) is about twice the height of the drainage area of La Gileppe reservoir.

As detailed in Fig. 1, both reservoirs are fed by their own upstream subcatchments; but also by two additional rivers from which diversion tunnels were built. For the Eupen dam, the River Helle is diverted and increases the effective catchment area from 7000 to 10500 ha. For La Gileppe dam, the River Soor is deviated to increase the catchment area from 3500 to 5500 ha. Both tunnels are usually open and only a minimum environmental flow remains in the rivers Soor and Helle downstream of the water intakes. As detailed below, if the reservoirs reach their maximum water levels, these tunnels can be closed and all the discharge can be conveyed in the rivers Soor and Helle. The combined effect of both dams enables about one-quarter of the overall Vesdre catchment to be regulated, while three-quarters remain unregulated. In par- 
ticular, the unregulated tributary Hoëgne flows into the River Vesdre in Pepinster, causing periodic flood events.

The main objective of the reservoirs is the supply of drinking water throughout the year for more than 400000 inhabitants (total capacity of $110000 \mathrm{~m}^{3} \mathrm{day}^{-1}$ ). Additionally, a minimum free storage of approximately $3 \mathrm{hm}^{3}$ in each reservoir is used for flood control. Two other purposes of the reservoirs are, in decreasing order of priority, the hydropower production, for approximately 1500 households in Eupen, and the augmentation of low-flows.

\section{Integrated model of the catchment}

An integrated model of the Vesdre catchment was set up. It enables the determination of reservoir levels, hydraulic variables of the River Vesdre and flood risk.

\subsection{Hydrological model and flow routing}

The hydrological model (MOHICAN) used is spatially distributed and process-oriented. It consists in a rainfall-runoff model (EPICgrid) coupled with the one-dimensional hydraulic model Wolf1-D for flow routing.

The rainfall-runoff model was described by Sohier et al. (2009) and was recently used by Bauwens et al. (2011). It is a modified version of the EPIC model initially proposed by Williams et al. (1984). A complete mathematical description of the model EPIC is given by Sharpley and Williams (1990). In particular, the infiltration model used in EPIC is based on a storage routing technique to predict flow through each soil layer (Sharpley and Williams, 1990). A regular grid of $1 \mathrm{~km}^{2}$ was applied to cover the whole catchment of the River Vesdre. Each cell is divided into several hydrological response units (HRUs) based upon the soil description, the slope, landuse and meteorological data. The HRUs are simulated separately and the outputs of a cell are the weighted average of the HRU's outputs (Bauwens et al., 2011). Validation of the model is available in Sohier et al. (2009) and Sohier and Degré (2010).

The lateral inflows to the rivers, computed by the rainfallrunoff model, are next routed through the river network by means of the hydraulic model Wolf1-D. It solves the conservative form of the 1-D Saint Venant equations using a finite volume scheme and a self-developed flux-vector splitting technique (Kerger et al., 2011a, b, c). The resulting ordinary differential equations are integrated in time using an explicit Runge-Kutta scheme. The shock capturing property of the scheme enables the simulation of flow regime changes and hydraulic jumps. An original procedure based on Lagrange multipliers is applied to simulate river junctions. The model was used in a number of previous hydrological studies, such as Dewals et al. (2012) and Khuat Duy et al. (2010). Regular cell sizes of $200 \mathrm{~m}$ were used to discretize the whole river network.
Data needed to feed the model are measured series of temperatures and precipitations in the catchment. Simulations for the actual time period used records realized between 1961 and 2005 which were interpolated using Thiessen polygons.

The hydrological simulations were carried out at an hourly time step from 1961 to 2005; but the results are taken into account from 1974 to 2004 . The first 13 years were not considered in the analysis of the results to reduce the influence of the initial conditions (warm-up period) and the year 2005 was rejected because the input data were not available for the whole year.

For prospective analysis, the measured time series of temperature and precipitation were perturbed to reflect possible changes in climate. This was performed using the perturbation tool CCI-HYDR developed by Ntegeka et al. (2014) and previously used by Bauwens et al. (2011). Based on the results of regional climate models (RCMs) and global circulation models (GCMs), it applies an advanced perturbation method to perturb the measured time series of temperature and precipitation. In the advanced perturbation method, perturbations are applied to the historical time series in two steps: first the numbers of wet and dry days are perturbed in the time series, followed by rainfall intensity changes for the wet days in a quantile (or exceedance probability) dependent way (Ntegeka et al., 2014). The CCI-HYDR perturbation tool reproduces a limited number of scenarios (wet, dry), which are representative of the spectrum of possible climate evolutions, as obtained from various RCMs, GCMs, and emission scenarios. This is currently the most advanced tool readily available for impacts studies in Belgian catchments.

Two time horizons were considered (2020-2050 and 2070-2100) and, for each of them, two extreme scenarios (Table 2), corresponding to different greenhouse gases emission scenarios (IPCC, 2007). These scenarios correspond to climate evolutions which are particularly extreme for, respectively, low-flows and floods.

\subsection{Reservoir operation model}

Based on documents from the dam operator (SPW, 2008), a detailed model of the operation of the Eupen and La Gileppe reservoirs was developed in the context of this study. It provides the time evolution of reservoirs outflows and levels.

The priority purposes of both dams are the production of drinking water and the conservation of a base flow in the River Vesdre as well as in the reach from La Gileppe dam to the River Vesdre. These discharges are about $40 \mathrm{~L} \mathrm{~s}^{-1}$ in each river. For drinking water, constant productions of $30000 \mathrm{~m}^{3} \mathrm{day}^{-1}$ at La Gileppe and $60000 \mathrm{~m}^{3} \mathrm{day}^{-1}$ at Eupen were assumed.

The two main modes of operation of the reservoirs correspond to "normal" and "flood management" conditions (Fig. 2).

The former mode is active for a reservoir provided that estimated water inflows into this reservoir during the next $48 \mathrm{~h}$ 


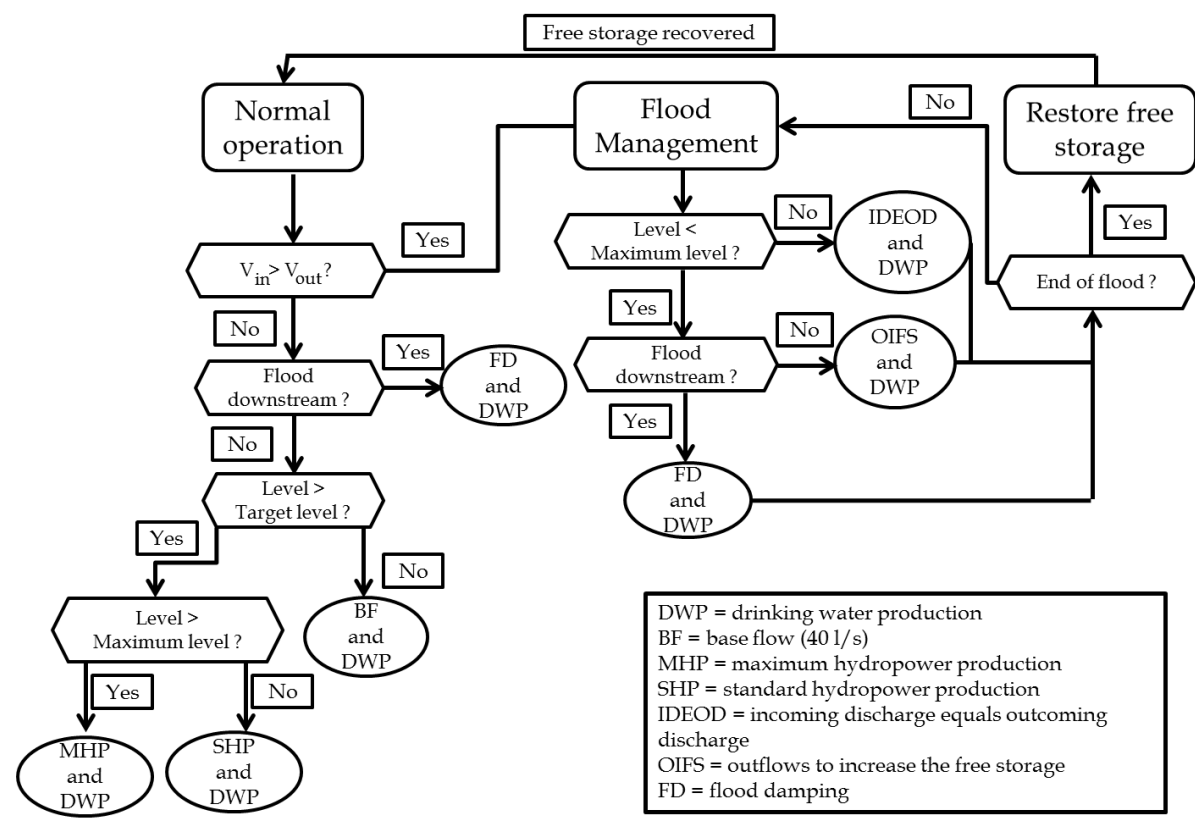

Figure 2. Principles of the reservoir operation rules.
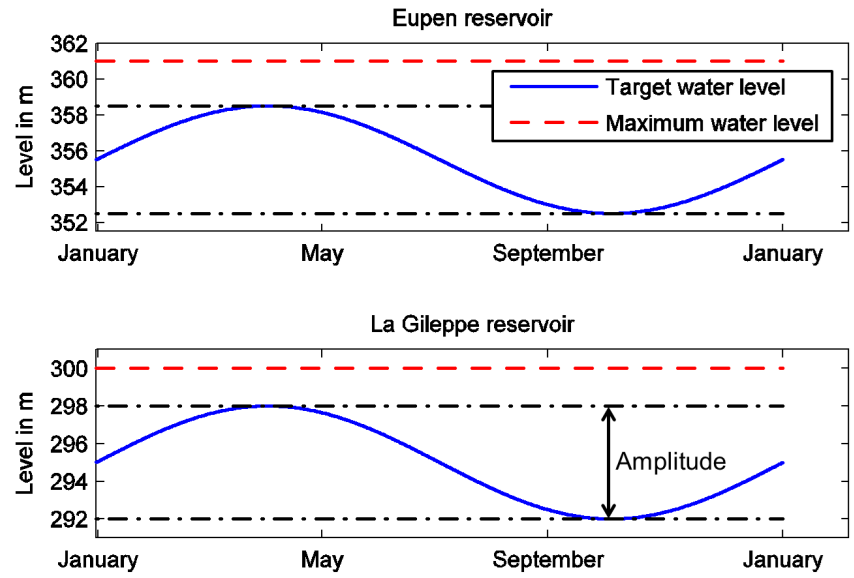

Figure 3. Target water levels and safety maximum water level in the Vesdre reservoirs.

do not exceed its free storage volume. These estimates of inflows are considered here as exact, while in reality they result from hydro-meteorological forecasts which contain some degree of uncertainty (Camnasio and Becciu, 2011). The contribution of water diverted by the tunnels is accounted for in these estimates.

In addition, two reference water levels are set in each reservoir (Fig. 3). First, a prescribed "maximum water level" may not be exceeded in each reservoir (Table 1), so as to keep a free storage of about $3 \times 10^{6} \mathrm{~m}^{3}$ in each reservoir for floods. If this water level is exceeded in the normal mode, maximum hydropower (Table 1) is produced until the maximum level is reached again. In the flood management mode, an extra dis-
Table 1. Summary of the reservoir characteristics.

\begin{tabular}{lcc}
\hline & Eupen & La Gileppe \\
\hline Capacity & $25 \times 10^{6} \mathrm{hm}^{3}$ & $26.4 \times 10^{6} \mathrm{hm}^{3}$ \\
Dam height & $66 \mathrm{~m}$ & $68 \mathrm{~m}$ \\
Natural river & Vesdre and Getzbach & La Gileppe \\
Natural drainage area & $6920 \mathrm{ha}$ & $3430 \mathrm{ha}$ \\
$\begin{array}{l}\text { Diverted river } \\
\text { Extra drainage area }\end{array}$ & Helle & Soor \\
through water diversion & $3675 \mathrm{ha}$ & $1970 \mathrm{ha}$ \\
$\begin{array}{l}\text { Minimum pool level } \\
\text { for drinking water }\end{array}$ & $343 \mathrm{~m}$ & $284 \mathrm{~m}$ \\
Mean target level & $355.5 \mathrm{~m}$ & $295 \mathrm{~m}$ \\
Maximum water level & $358.5 \mathrm{~m}$ & $298 \mathrm{~m}$ \\
Maximum safety level & $361 \mathrm{~m}$ & $300 \mathrm{~m}$ \\
Crest level & $362 \mathrm{~m}$ & $305 \mathrm{~m}$ \\
Maximum & & \\
hydropower discharge & $4.5 \mathrm{~m}^{3} \mathrm{~s}^{-1}$ & $1.8 \mathrm{~m}^{3} \mathrm{~s}$ \\
\hline
\end{tabular}

Table 2. Scenarios of climate change.

\begin{tabular}{lccccc}
\hline Time period & 1974-2004 & 2020-2050 & 2070-2100 \\
\hline Scenario & $/$ & wet & dry & wet & dry \\
\hline
\end{tabular}

charge is released by the spillway to increase the free storage. The released discharge fulfils criteria of non-inundation downstream, at the gauging station of Pepinster. Second, a "target water level" is defined. It follows a sinusoidal evolution over each year (Fig. 3). Whenever the water level is in-between the target level and the maximum level, standard hydropower is produced $\left(1.5 \mathrm{~m}^{3} \mathrm{~s}^{-1}, 6 \mathrm{~h} \mathrm{day}^{-1}\right)$. In contrast, 
Table 3. Characteristic discharges at Chaudfontaine derived from observations and from computations.

\begin{tabular}{lrrr}
\hline $\begin{array}{l}\text { Return } \\
\text { Period (Year) }\end{array}$ & Measure & Simulation & $\begin{array}{r}\text { Relative } \\
\text { error }\end{array}$ \\
\hline 25 & $226 \mathrm{~m}^{3} \mathrm{~s}^{-1}$ & $210 \mathrm{~m}^{3} \mathrm{~s}^{-1}$ & $7 \%$ \\
50 & $241 \mathrm{~m}^{3} \mathrm{~s}^{-1}$ & $229 \mathrm{~m}^{3} \mathrm{~s}^{-1}$ & $5 \%$ \\
100 & $255 \mathrm{~m}^{3} \mathrm{~s}^{-1}$ & $247 \mathrm{~m}^{3} \mathrm{~s}^{-1}$ & $3 \%$ \\
\hline
\end{tabular}

if the water level drops below the target level, hydropower production is stopped.

After a flood, the operation mode of the reservoirs switches back to "normal" once the river discharge decreases at the junction between the River Hoëgne and the River Vesdre, and the water level in the reservoir drops below the normal water level. To enable this, $20 \mathrm{~m}^{3} \mathrm{~s}^{-1}$ at Eupen reservoir and $10 \mathrm{~m}^{3} \mathrm{~s}^{-1}$ at La Gileppe reservoir are released when the discharge at a gauging station downstream of the dams becomes lower than $50 \mathrm{~m}^{3} \mathrm{~s}^{-1}$. In this phase, the diversion tunnels are both closed to foster a quick recovery of free storage capacity in the reservoirs.

For the Vesdre catchment, the model was validated by comparing time evolutions of computed and measured discharges at Chaudfontaine for entire years and for several major floods (Magermans et al., 2011), as well as estimates of flood frequency at the same gauging station, derived from computations and from observations (Table 3). Chaudfontaine is the only gauging station where reliable data are available for the whole control period.

\subsection{Flood frequency analysis and low-flow statistics}

Flood frequency analysis was performed based on the annual maximum hourly discharge of the computed time series. The Weibull distribution was used, as recommended by Bauwens et al. (2011) for the River Vesdre. The mean daily discharge not reached 10 days per year in a flow-duration curve (DCE) was also estimated and was used as an indicator of low-flows. The flood frequency relationship changes from upstream to downstream. To handle this variation in space, the whole course of the River Vesdre was separated here in three reaches: upper, middle and lower reach (Fig. 1). Each reach is delimited by the junction of the River Vesdre with a major tributary. Next, flood frequency analysis was performed for three specific locations, each of them being located in one of the three reaches. The relationships between return periods and characteristic flood discharges obtained from these three flood frequency analyses were each considered as representative of the corresponding reach.

The results of the runs of the hydrological model performed for climate change conditions enabled the flood frequencies to be updated for the future time horizons.

\subsection{Inundation modelling}

For the peak flood discharges estimated for different return periods, detailed inundation modelling using the hydraulic model WOLF 2-D was conducted for the whole valley of the River Vesdre $(\sim 40 \mathrm{~km})$, from the Eupen reservoir to the mouth of the River Vesdre into the River Ourthe (in Chênée, close to Liege). The model solves the fully dynamic shallowwater equations using a conservative finite volume scheme based on a flux vector splitting technique (Dewals et al., 2008; Erpicum et al., 2010b).

The model was extensively validated for inundation modelling along over $1300 \mathrm{~km}$ of rivers (Erpicum et al., 2010a, b), as well as for other complex turbulent flow (Camnasio et al., 2013; Dewals et al., 2008; Erpicum et al., 2009; Roger et al., 2009). It provides detailed spatially distributed results throughout the floodplains (Beckers et al., 2013; Dewals et al., 2011; Ernst et al., 2010).

The topographic model is based on a Lidar altimetry for the floodplain, with a grid size of $2 \times 2 \mathrm{~m}^{2}$ and an accuracy of $15 \mathrm{~cm}$ in elevation, and cross-sections every $50 \mathrm{~m}$ for the river bathymetry. The friction coefficient was calibrated by comparing numerical results to observed inundation extents during the 1998 flood.

Seven different peak flood discharges were considered here for inundation modelling, including those corresponding to the return periods $25(\mathrm{Q} 25), 50(\mathrm{Q} 50)$ and 100 years $(\mathrm{Q} 100)$ in the reference situation. The discharges $\mathrm{Q} 100+15 \%$ and $\mathrm{Q} 100+30 \%$ were also considered because they are of the order of future 100-year discharges for, respectively, 2020-2050 and 2070-2100 (last line of Table 8). To better approximate the risk curve for highprobability floods, a discharge corresponding to relatively low damages $\left(150 \mathrm{~m}^{3} \mathrm{~s}^{-1}\right.$ in Chaudfontaine) and one corresponding to the estimated bankfull discharge in Chaudfontaine $\left(120 \mathrm{~m}^{3} \mathrm{~s}^{-1}\right)$ were also considered for inundation modelling. The corresponding discharges are assumed to be uniform within a reach, but are altered at each junction with a major tributary.

The peak discharge of the highest historical flood (1998) is evaluated at $241 \mathrm{~m}^{3} \mathrm{~s}^{-1}$, which is very close to the estimated 100-year flood discharge Q100 (Table 3). However, to derive valid risk curves, higher discharges, up to $\mathrm{Q} 100+30 \%$, were considered for inundation modelling. Since the highest flood on record is the 1998 flood (close to Q100), it was not possible to recalibrate the hydraulic model for discharges as high as Q100+30\%. Therefore, the initial calibration was assumed to remain valid also for higher discharges.

\subsection{Damage}

The distribution of land-use categories was obtained by combining the localization plan (PLI) and the sector plan (PdS) obtained from the Walloon Region (Beckers et al., 2013). For each land-use category, a damage function provides the rela- 
tionship between water depth and relative damage. This relative damage (in \%) in an area expresses the potential damage for a given flood scenario as a percentage of the maximum possible damage in this area (Merz et al., 2010b). The damage functions considered here are the FLEMO curves (Vorogushyn et al., 2012, Kreibich et al., 2010, Thieken et al., 2008) for residential land-use categories and the IKSR curves (Rhine Atlas) for agriculture, forests and infrastructure. For a given flood discharge, by combining the inundation map computed by Wolf2-D, the land-use map and the damage functions, the relative damage was obtained for each area in \%. Then, this relative damage was converted into absolute damage (in EUR) by multiplying the relative damage of each area by the asset value associated with its land-use category (in EUR m ${ }^{-2}$ ). Asset values were based on the ATKIS prices developed in Germany and adapted to the Walloon Region. Finally, all contributions to the damage were summed for each reach of the River Vesdre. In this study, only direct and tangible damages were considered, with a micro-scale approach applied only for immobile residential damage and a meso-scale approach for other damage categories (Sinaba et al., 2013).

\subsection{Risk}

The flood risk corresponds to the mean annual damage expected in an area due to flood events (Merz et al., 2010a). A risk curve represents the total flood damage (in EUR) as a function of the cumulative flood frequency associated with the corresponding discharges (Kaplan and Garrick, 1981). Thanks to the flood frequency analysis achieved for the three reaches, a risk curve could be obtained for each locality from the seven flood discharges for which flood damages were estimated. The maximum return period considered in the risk analysis is around 5000 years in the present situation at Chaudfontaine (lower reach), corresponding to the discharge $\mathrm{Q} 100+30 \%$. To evaluate the risk from the seven values of damage estimated for the characteristic flood discharges, a two-step procedure is followed:

- first, a two-parameter logarithmic function is fitted on the available damage estimates (Fig. 8);

- second, this logarithmic function is integrated analytically over the whole range of flood frequencies (i.e. from 0 to 1 ).

This enables a maximum coverage of the whole spectrum of possible flood events and it also reduces quadrature errors.

\section{Sensitivity analysis}

\subsection{Indicators of reservoir system performance}

Performance indicators were defined to analyse the impacts of climate change on the reservoir performance and to ex-
Table 4. Indicators for the reservoir purposes.

\begin{tabular}{lll}
\hline Parameter & Indicator & Unity \\
\hline$y_{1}$ & Flood risk & $\mathrm{EUR} \mathrm{yr}^{-1}$ \\
$y_{2}$ & Mean annual hydropower potential & $\mathrm{kWh} \mathrm{yr}^{-1}$ \\
$y_{3}$ & Minimum daily level of Eupen reservoir & $\mathrm{m}$ \\
$y_{4}$ & Minimum daily level of La Gileppe reservoir & $\mathrm{m}$ \\
$y_{5}$ & Mean annual DCE & $\mathrm{m}^{3} \mathrm{~s}^{-1}$ \\
\hline
\end{tabular}

plore possible improvements in the operation rules of the reservoirs. One indicator $y_{j}$ was defined for each purpose of the dams (Table 4). In addition to flood risk, the indicators include the mean annual hydropower potential, the minimum daily level in each reservoir and the mean annual DCE.

\subsection{Metrics for sensitivity analysis}

Local sensitivity analysis was used to assess the sensitivity of the system around a single set of parameter values (Wildemeersch et al., 2014). Although theoretically not adapted to nonlinear systems like dam management, this method remains appealing due to the relatively low number of necessary model runs. Also, as shown by Hill and Tiedeman (2007), the method remains generally valid in practice, except for extremely non-linear systems. From model runs exploring the impacts of operating rule parameters $b_{i}$ on indicators $y_{j}$, a sensitivity matrix $\mathbf{J}$ was obtained:

$\mathbf{J}=\left(\begin{array}{ccc}\left.\frac{\partial y_{1}}{\partial b_{1}}\right|_{b} & \cdots & \left.\frac{\partial y_{1}}{\partial b_{\text {npar }}}\right|_{b} \\ \vdots & \ddots & \vdots \\ \left.\frac{\partial y_{\text {nind }}}{\partial b_{1}}\right|_{b} & \cdots & \left.\frac{\partial y_{\text {nind }}}{\partial b_{\text {npar }}}\right|_{b}\end{array}\right)$.

A quantitative analysis was then realized using the dimensionless scaled sensitivities dss $i j$ :

$\operatorname{dss}_{i j}=\left.\frac{\partial y_{i}}{\partial b_{j}}\right|_{b} \cdot\left|b_{j}\right| \cdot\left|\frac{1}{y_{i}}\right| \cdot$

For indicators and parameters related to the reservoir levels, the variations of $b_{i}$ and $y_{j}$ were compared with the minimum pool level for drinking water (Table 1).

\subsection{Procedure}

Since the influence of the operation rules parameters need to be known to guide the development of enhanced operation rules, the influence of each of these parameters on the reservoirs performance was analysed. In addition to the main parameters listed in Table 5, the influence of the following less-influencing parameters was also studied: discharge released after a flood to restore the initial storage capacity, the management of the Soor and Helle tunnels and other specific parameters. The discharge threshold at Pepinster (Tests 7 and 
Table 5. Main parameters of the operation rules.

\begin{tabular}{lll}
\hline Test & Parameter modified & Reference value \\
\hline 1 & Daily duration of the standard hydropower production & $6 \mathrm{~h} \mathrm{day}^{-1}$ \\
2 & Mean target water level at Eupen reservoir & $355.5 \mathrm{~m}$ \\
3 & Mean target water level at La Gileppe reservoir & $295 \mathrm{~m}$ \\
4 & Amplitude of time evolution of the target water level at Eupen reservoir & $6 \mathrm{~m}$ \\
5 & Amplitude of time evolution of the target water level at La Gileppe reservoir & $6 \mathrm{~m}$ \\
6 & By-pass discharge at each reservoir & $0,04 \mathrm{~m}^{3} \mathrm{~s}^{-1}$ \\
7 & Discharge threshold at Pepinster for detecting flood downstream in the "normal" mode & $90,5 \mathrm{~m}^{3} \mathrm{~s}^{-1}$ \\
8 & Discharge threshold at Pepinster for detecting flood downstream in the "flood management" mode & $90,5 \mathrm{~m}^{3} \mathrm{~s}^{-1}$ \\
9 & Drinking water production at Eupen reservoir & $60000 \mathrm{~m}^{3} \mathrm{day}^{-1}$ \\
10 & Drinking water production at La Gileppe reservoir & $30000 \mathrm{~m}^{3} \mathrm{day}^{-1}$ \\
\hline
\end{tabular}

8) was varied to quantify its effect on the maximum releases avoiding flood downstream both in the "normal" and in the "flood management" modes.

\subsection{Results and discussion}

A substantial share (89\%) of overall flood risk in the present situation is due to the subcatchment corresponding to the lower reach (with $11 \%$ for the middle reach and a negligible share for the upper reach).

The efficiency $R$ of the present operation rules was compared to two extreme situations, corresponding, respectively, to no retention capacity $R_{0}$ and an infinite retention capacity $R_{\infty}$ (Table 6). Equation (3) gives the maximum flood mitigation potential, Eq. (4) provides the absolute reservoir efficiency and Eq. (5) corresponds to the relative reservoir efficiency. Multiplying Eqs. (3) and (5) gives Eq. (4):

Mitigation potential $=\frac{R_{0}-R_{\infty}}{R_{0}}$

Absolute reservoir efficiency $=\frac{R_{0}-R}{R_{0}}$

Relative reservoir efficiency $=\frac{R_{0}-R}{R_{0}-R_{\infty}}$.

The variations of operation rules parameters and their influences on the performance indicators are given in Table 7 . Applying the local sensitivity method leads to the results detailed in Fig. 4. For each parameter of the operation rules, reasonable variations were selected based on engineering judgement.

First, a significant part of flood risk in the Vesdre catchment is due to the lower part of the valley, where only a quarter of the catchment is regulated by the dams. This flood risk accounts for nearly EUR 4 million $\mathrm{yr}^{-1}$. For the regulated part of the catchment, the operation of the reservoirs is relatively efficient for flood mitigation with a total relative
Table 6. Reservoir efficiencies and mitigation potential for the reservoirs operation rules in the present situation.

\begin{tabular}{lrrrr}
\hline & $\begin{array}{r}\text { Upper } \\
\text { reach }\end{array}$ & $\begin{array}{r}\text { Middle } \\
\text { reach }\end{array}$ & $\begin{array}{r}\text { Lower } \\
\text { reach }\end{array}$ & Total \\
\hline Mitigation potential & $100 \%$ & $91 \%$ & $60 \%$ & $73 \%$ \\
Absolute reservoir efficiency & $100 \%$ & $87 \%$ & $55 \%$ & $69 \%$ \\
Relative reservoir efficiency & $100 \%$ & $95 \%$ & $93 \%$ & $95 \%$ \\
\hline
\end{tabular}

efficiency of $95 \%$ (Table 6). This relative efficiency (Eq. 5) is lower in the lower reach than in the upper one, partly because of the time delay between decisions made at the dams and their effects downstream. For this reason, a total relative efficiency of $100 \%$ is not achievable based on reservoir operating rules not taking into account wave propagation downstream. The presence of the reservoirs enables a complete reduction of flood risk in the upper reach, a very strong decrease in the middle reach (87\%), upstream of the junction with the River Hoëgne, and a decrease by almost $55 \%$ in the lower reach. The absolute efficiency (Eq. 4) is higher in the upper reach than in the lower one, mainly, because of the higher share of the catchment which is regulated.

Second, dimensionless scaled sensitivity values, obtained for the low-flow indicator (DCE), are much lower in absolute values than the values obtained for the other indicators (Fig. 4). However, the model structure and its calibration were mainly focused on flood modelling and, therefore, simplifications remain in the groundwater flow modelling leading to more uncertainties for low-flow predictions by the model than for flood reproduction. The parameter "dss" takes higher absolute values for the minimum daily level in La Gileppe reservoir than in Eupen, due to a catchment area which is 2 times higher for Eupen while the storage capacities are equivalent. Indicators relative to the minimum reservoir levels reveal a much higher sensitivity than the others, two "dss" values being higher or equal to unity at each reservoir. Finally, the reservoir operation rules have a low effect on hydropower production since increasing the amount of 
Table 7. Variations of operating rule parameters $\left(b_{i}\right)$ and their incidences on indicators $\left(y_{j}\right)$.

\begin{tabular}{ccrrrrr}
\hline $\begin{array}{c}\text { Performance } \\
\text { indicator }\end{array}$ & & $\begin{array}{r}y_{1} \\
\left(10^{3} \mathrm{EUR} \mathrm{yr}^{-1}\right)\end{array}$ & $\begin{array}{r}y_{2} \\
\left(\mathrm{MWh} \mathrm{yr}^{-1}\right)\end{array}$ & $\begin{array}{r}y_{3} \\
(\mathrm{~m})\end{array}$ & $\begin{array}{r}y_{4} \\
(\mathrm{~m})\end{array}$ & $\begin{array}{r}y_{5} \\
\left(\mathrm{~m}^{3} \mathrm{~s}^{-1}\right)\end{array}$ \\
\hline Test & Reference & 4200 & 8600 & 351.5 & 291.5 & 1.65 \\
& $\Delta b_{i}$ & $\Delta y_{1}$ & $\Delta y_{2}$ & $\Delta y_{3}$ & $\Delta y_{4}$ & $\Delta y_{5}$ \\
\hline 1 & $+9 \mathrm{~h} \mathrm{day}^{-1}$ & $-3.8 \%$ & $-1.2 \%$ & -0.29 & -0.29 & $-21.8 \%$ \\
2 & $-2 \mathrm{~m}$ & $-5.5 \%$ & $-1.2 \%$ & -2.28 & 0 & $-1.2 \%$ \\
3 & $-2 \mathrm{~m}$ & $-1.9 \%$ & $-0.2 \%$ & 0 & -2.16 & $-0.6 \%$ \\
4 & $-2 \mathrm{~m}$ & $0.0 \%$ & $0.2 \%$ & 1.75 & 0 & $-2.4 \%$ \\
5 & $-2 \mathrm{~m}$ & $0.0 \%$ & $0.2 \%$ & 0 & 1.84 & $-3.0 \%$ \\
6 & $+0.06 \mathrm{~m}^{3} \mathrm{~s}^{-1}$ & $-0.2 \%$ & $-7.9 \%$ & -0.68 & -0.49 & $4.2 \%$ \\
7 & $-10 \mathrm{~m}^{3} \mathrm{~s}^{-1}$ & $-0.7 \%$ & $-0.2 \%$ & 0 & 0 & $0.0 \%$ \\
8 & $+10 \mathrm{~m}^{3} \mathrm{~s}^{-1}$ & $4.3 \%$ & $0.1 \%$ & 0 & 0 & $0.0 \%$ \\
\hline 9 & $+30000 \mathrm{~m}^{3}$ day $^{-1}$ & $-1.7 \%$ & $-18.5 \%$ & -4.28 & 0 & $-7.9 \%$ \\
10 & $+30000 \mathrm{~m}^{3}$ day $^{-1}$ & $-2.6 \%$ & $-17.2 \%$ & 0 & -16.70 & $-12.1 \%$ \\
\hline
\end{tabular}

(a) $y_{1}=$ Flood risk

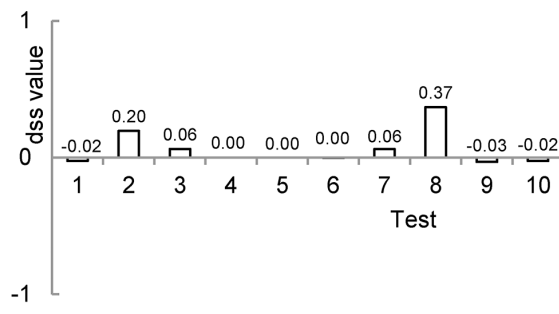

(c)

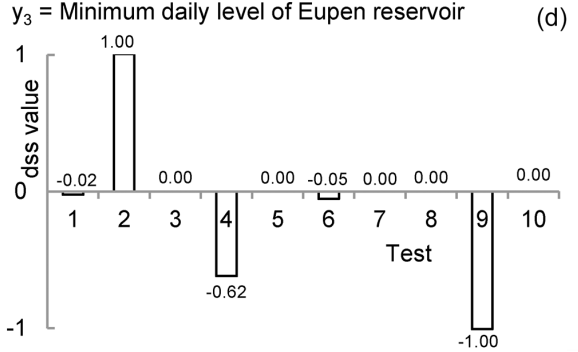

(e) (b) $y_{2}=$ Mean annual hydropower potential

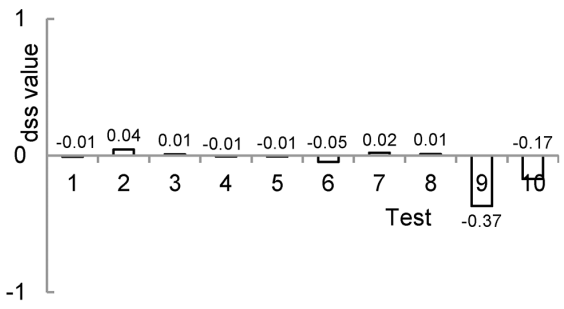

(d) $y_{4}=$ Minimum daily level of La Gileppe reservoir

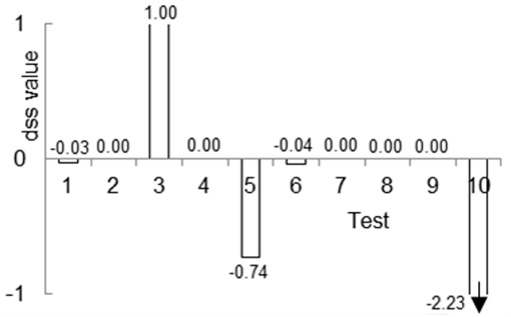

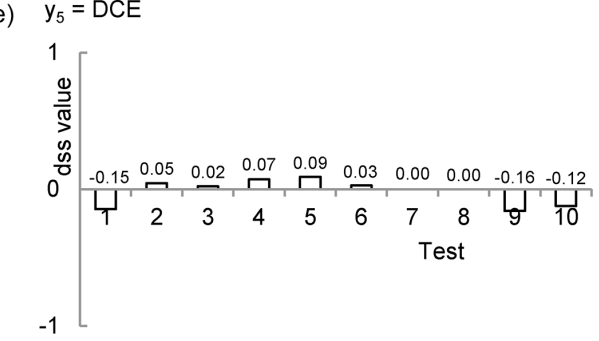

Figure 4. Local sensitivity analyses of the operation rules parameters.

water used for hydropower production simultaneously decreases the available head.

The low-flow indicator is highly dependent on the amount of water released for hydropower production during the dry season. An increase in the duration of the standard hydropower production reduces significantly the DCE (Test 1).
Indeed, this modification leads to a reduction of the reservoir water levels which reach more quickly the target water levels. Below these target water levels, the hydropower production is stopped (Fig. 2).

The mean target water level in each reservoir (Tests 2 and 3 ) has an influence on all indicators. A reduction of this mean 
A)

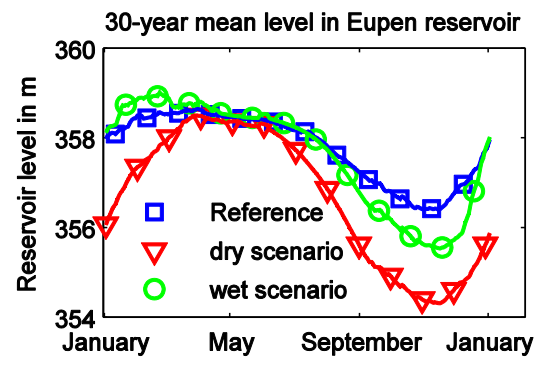

C)

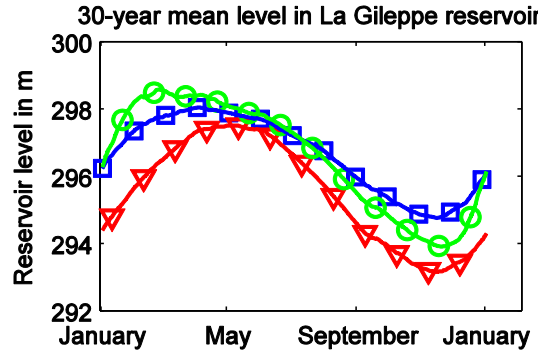

B)

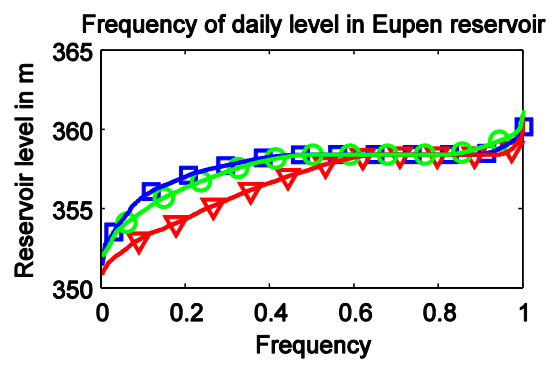

D)

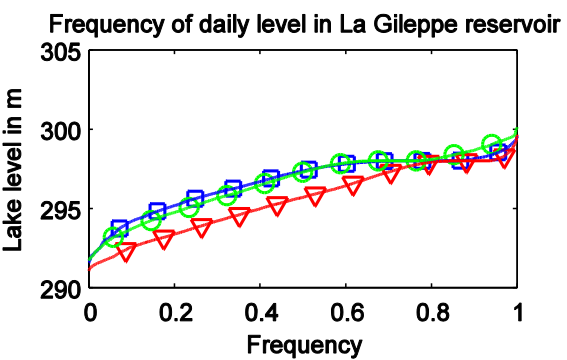

Figure 5. Impacts of climate change on the reservoir levels in the time period 2070-2100.

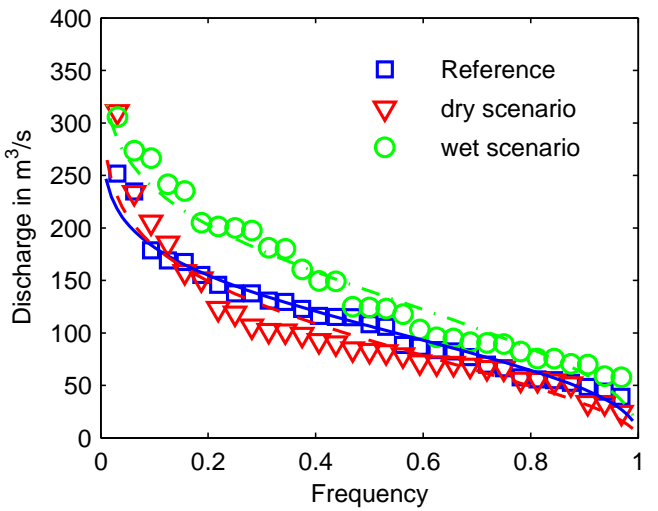

Figure 6. Cumulative frequency distribution of flood discharges in Chaudfontaine (lower reach) in the present situation and in the time period 2070-2100. Discrete points are results from discharge time series obtained from the hydraulic model WOLF1-D and curves correspond to fitted Weibull distributions.

level at one reservoir enables an increase in available storage for flood control, but leads also to a decrease in the minimum levels reached by the reservoir, impairing the guarantee of sufficient drinking water availability. A decrease in the amplitudes of the time evolution of the target water levels (Tests 4 and 5) leads mainly to an increase in lowest reservoir levels and to slight decrease in the low-flow discharge. Therefore, varying the amplitude of the time evolution of a target level enables a direct control of the minimum reservoir level without impacting flood risk. So, target water levels are parameters that can be used to modify the minimum levels reached by the reservoirs and to reduce flood risk, as also highlighted by Bieri et al. (2011) for the upper Aare catchment.

A change in the by-pass discharges (Test 6) implies obviously a decrease in drinking water reserve and in hydropower production. This trade-off between hydropower production and non-turbined water uses is in agreement with the conclusions of Payne et al. (2004) for the Columbia River basin. The relatively low value of the indicator of low-flow is attributed to the previously mentioned high dependency of this indicator on the hydropower production during the dry season.

The threshold discharges used for detecting flood downstream in the "normal" mode and in the "flood management" mode (Tests 7 and 8) have a significant influence only on flood risk. In the "flood management" mode (Test 8), this threshold discharge is the main parameter influencing flood risk. Although an increase in the discharges downstream could have a beneficial influence by reducing the rate of filling of the reservoirs during a flood event, the increase of the threshold discharge has a detrimental effect on flood risk as it leads to higher damage downstream. The results suggest that these threshold discharges should be decreased.

A change in the demand for drinking water (Scenarios 9 and 10) has a very substantial influence on the minimum daily reservoir levels, on the hydropower potential and on the low-flow augmentation. A given increase in drinking water production has an influence twice as strong on the low reservoir levels in La Gileppe than in Eupen as a result of the difference in the reservoir catchment areas. 

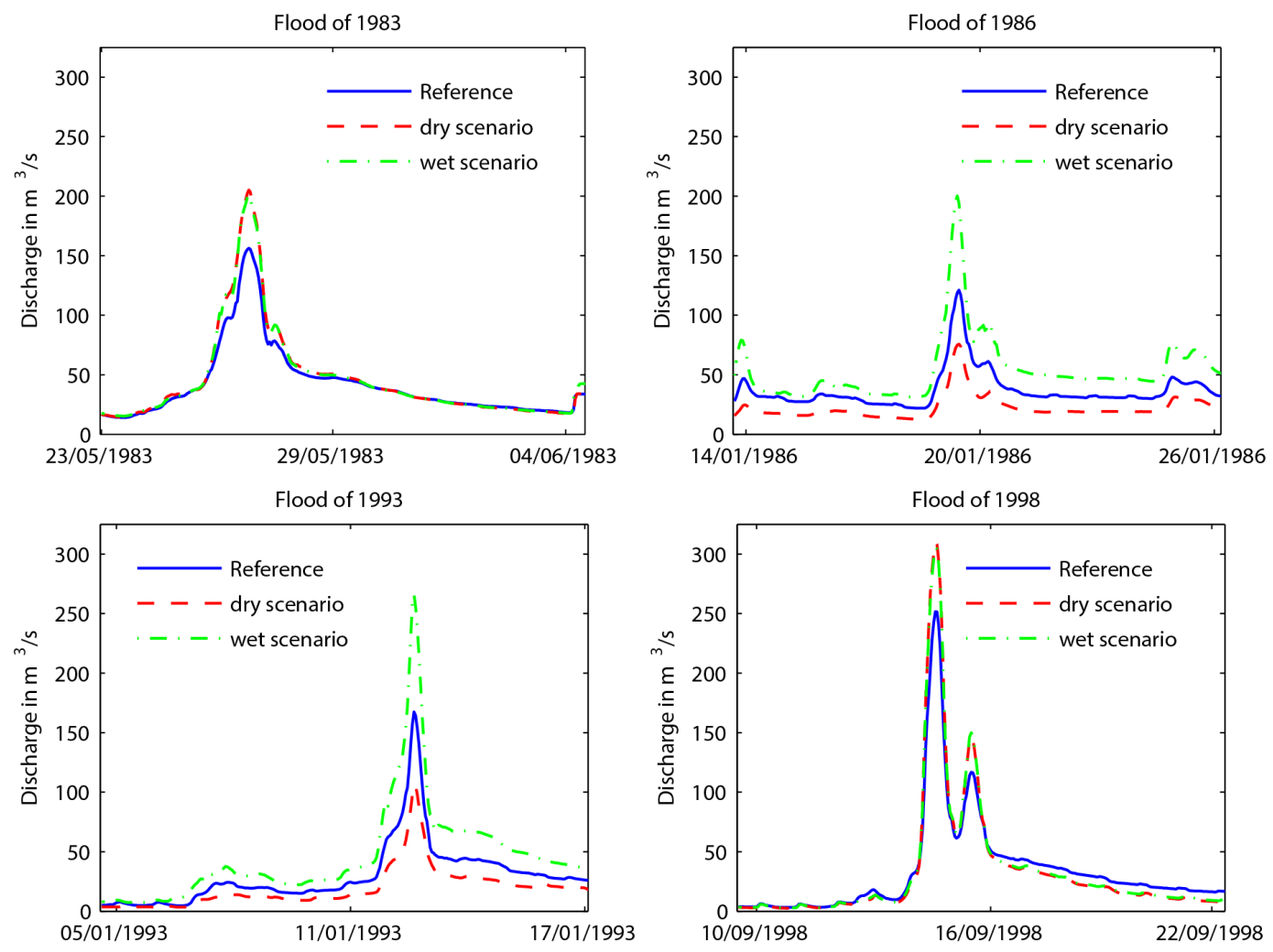

Figure 7. Flood hydrographs in Chaudfontaine (lower reach) for four major floods in the present situation and in the time period 2070-2100.

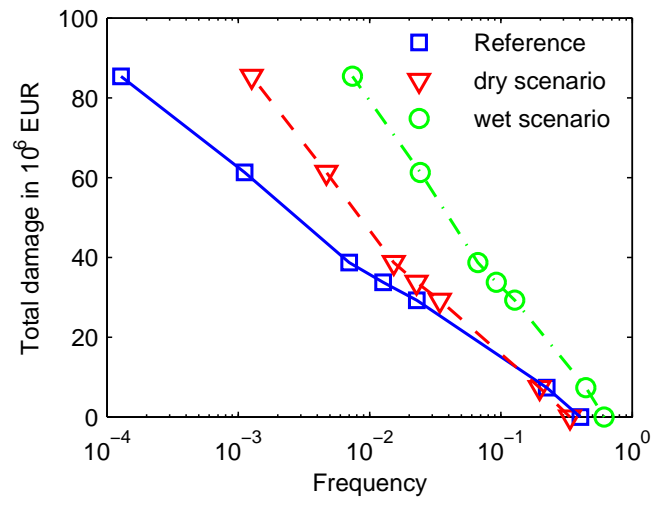

Figure 8. Risk curve in Chaudfontaine (lower reach) in the present situation and in the time period 2070-2100.

\section{Influence of climate change}

For the time period 2070-2100, the mean annual reservoir levels were modified as presented in Fig. 5. In winter, the mean reservoir levels increase in the wet scenario. In autumn, the mean reservoir levels drop for both scenarios but mainly for the dry one. Despite these substantial changes, the minimum daily levels in Eupen and La Gileppe reservoirs vary only slightly because the operation rules limit the hydropower production if the reservoir levels are below the target water level.

The flood-frequency curves for the reference situation and for the time horizon 2070-2100 are given in Fig. 6. For the wet scenario, the flood-frequency curve evolves towards a general increase in the discharge values, inducing strong increases in flood risk. The 100 -year flood discharge rises by $32 \%$ for the time horizon $2070-2100$, which is very close to the results of Dewals et al. (2013). For the dry scenario, only the highest discharges are increased while the other discharges are reduced, leading nonetheless to a slight increase in flood risk. In Fig. 7, examples of flood hydrographs for future time periods 2070-2100 are compared to the reference hydrographs for four major floods (1983, 1986, 1993 and 1998) in Chaudfontaine (lower reach). For each of them, the peak discharge in the wet scenario is higher than in the reference situation. For the floods of January 1986 and 1993, the peak discharges in the dry scenario are lower than the peak discharges in the reference situation while they are of the same order as the peak discharges in the wet scenario for the floods of May 1983 and September 1998.

The seven values of damage estimated for the characteristic flood discharges are presented in the risk curves of Fig. 8 for the reference situation and the time horizon 2070-2100. They confirm that for the lowest flood frequencies, both climate scenarios (wet and dry) lead to increased damages. 
Table 8. Influence of climate change.

\begin{tabular}{llrrrr}
\hline & & \multicolumn{2}{c}{$2020-2050$} & \multicolumn{2}{c}{$2070-2100$} \\
\cline { 3 - 5 } & & Scenario & Wet & Dry & Wet \\
\hline$y_{1}$ & Flood risk & $+25 \%$ & $+35 \%$ & $+8 \%$ & $+200 \%$ \\
$y_{2}$ & Mean annual hydropower potential & $-10 \%$ & $+11 \%$ & $-35 \%$ & $+15 \%$ \\
$y_{3}$ & Minimum daily level of Eupen reservoir & $-50 \mathrm{~cm}$ & $+50 \mathrm{~cm}$ & $-60 \mathrm{~cm}$ & $+50 \mathrm{~cm}$ \\
$y_{4}$ & Minimum daily level of La Gileppe reservoir & $-10 \mathrm{~cm}$ & $+10 \mathrm{~cm}$ & $-50 \mathrm{~cm}$ & $+20 \mathrm{~cm}$ \\
$y_{5}$ & Mean annual DCE & $-8 \%$ & $+3 \%$ & $-15 \%$ & $\pm 0 \%$ \\
Mean reservoir inflows & $-11 \%$ & $+16 \%$ & $-20 \%$ & $+20 \%$ \\
Q100 at Chaudfontaine & $+14 \%$ & $+25 \%$ & $+10 \%$ & $+32 \%$ \\
\hline
\end{tabular}

The influence of the climate change scenarios on the reservoirs performance is summarized in Table 8.

For the time period 2020-2050, hydropower potential varied between $-35 \%$ (dry) and $+15 \%$ (wet) as a result of a change in the mean annual reservoir inflows of, respectively, $-20 \%\left(270 \mathrm{hm}^{3}\right)$ and $+20 \%\left(410 \mathrm{hm}^{3}\right)$. The hydropower potential shows a higher sensitivity with respect to climate change than to the reservoirs' management parameters. The 100-year flood discharge in Chaudfontaine increased by $32 \%\left(322 \mathrm{~m}^{3} \mathrm{~s}^{-1}\right)$ in the wet scenario and by $10 \%\left(269 \mathrm{~m}^{3} \mathrm{~s}^{-1}\right)$ in the dry one. Flood risk rises substantially, between $8 \%$ (EUR $4520000 \mathrm{yr}^{-1}$ ) to $200 \%$ (EUR $12650000 \mathrm{yr}^{-1}$ ) for the entire catchment. A decrease by $15 \%$ of the mean annual DCE is consistent with the results of Magermans et al. (2011) for the dry scenario, whereas it did not change in the wet one.

For the time period 2020-2050, minimum daily reservoir levels were slightly modified. The low-flows indicator was decreased by $8 \%$ in the dry scenario and the variations of the hydropower potential were between -10 and $+10 \%$, revealing again that climate change may have a beneficial effect on hydropower production. This time, flood risk rose by 25 to $135 \%$, depending on the scenario (dry or wet).

Results of the simulations vary widely between the wet and the dry scenario. Despite these large variations, common tendencies can be highlighted: a decrease in the reservoirs levels in autumn, an increase in the frequency of levels reaching the maximum safety level, a decrease or a status quo for the low-flow intensities and an increase in flood risk.

\section{Perspective of improved reservoir operation}

The influence of the reservoir management parameters and of climate change on the indicators of reservoir performance is summarized qualitatively in Table 9. The direction (up vs. down) and the thickness of the arrows represent, respectively, the direction (increase vs. decrease) and the relative magnitude of the variation.

Despite a rise in flood risk, to a different extent depending on the scenario and the time horizon, the perspective of enhancing flood control by means of improved reservoir opera- tion is strongly hampered by the already quasi-optimal management of the reservoirs in this respect (relative reservoir efficiency $>90 \%$ ). Indeed, in the wet scenario for the time period 2070-2100, assuming an infinite retention capacity $R_{\infty}$ in Eupen and La Gileppe reservoirs leads to a residual flood risk as high as EUR $11850000 \mathrm{yr}^{-1}$ for the entire catchment. Since the corresponding risk obtained with the present operation rules equals EUR $12600000 \mathrm{yr}^{-1}$ (see reference value in Table 7 , and increase by $200 \%$ according to Table 8 ), an enhancement of the reservoir operation rules to mitigate flood risk is limited to a potential reduction of maximum $6 \%$ for this extreme scenario. Nonetheless, two perspectives of improvement of the reservoir operation may contribute to mitigate the impacts of climate change on flood risk. The former consists in a reduction of the mean target level, inducing a significant reduction of the minimum reservoir level. To compensate this reduction of the minimum reservoir level, the amplitude of the time evolution of the target level may be decreased without inducing extra flood risk. The second perspective is a reduction of the discharge threshold for detecting flood downstream in the "flood management" mode, which has no influence on the other performance indicators.

In order to demonstrate the applicability of the findings of the sensitivity analysis performed in the reference situation to propose perspectives of improved reservoir operation in future time periods, the effects of the two recommended changes in the operation rule parameters have been simulated for the time period 2070-2100 (wet scenario). From Fig. 4a, the mean target water levels (Tests 2 and 3 ) and the discharge threshold at Pepinster for detecting flood downstream in the "flood management" mode (Test 8) appear to be the operation rule parameters having the highest influence on flood risk. For mean water levels of $353.5 \mathrm{~m}(-2 \mathrm{~m})$ and $294 \mathrm{~m}(-1 \mathrm{~m})$, respectively in Eupen and La Gileppe reservoirs, and a discharge threshold at Pepinster of $80.5 \mathrm{~m}^{3} \mathrm{~s}^{-1}$ $\left(-10 \mathrm{~m}^{3} \mathrm{~s}^{-1}\right)$, the flood risk is reduced by EUR $300000 \mathrm{yr}^{-1}$ $(-2 \%)$ and the minimum reservoir levels in Eupen and $\mathrm{La}$ Gileppe reservoirs decrease by, respectively, 2.3 and $1.1 \mathrm{~m}$. Hence, the variations of the minimum reservoir levels are consistent with Table 7 while the reduction of the flood risk remains limited by the maximum potential reduction $(6 \%)$. 
Table 9. Qualitative influence of the reservoir management parameters and of climate change on the indicators of reservoir performance.

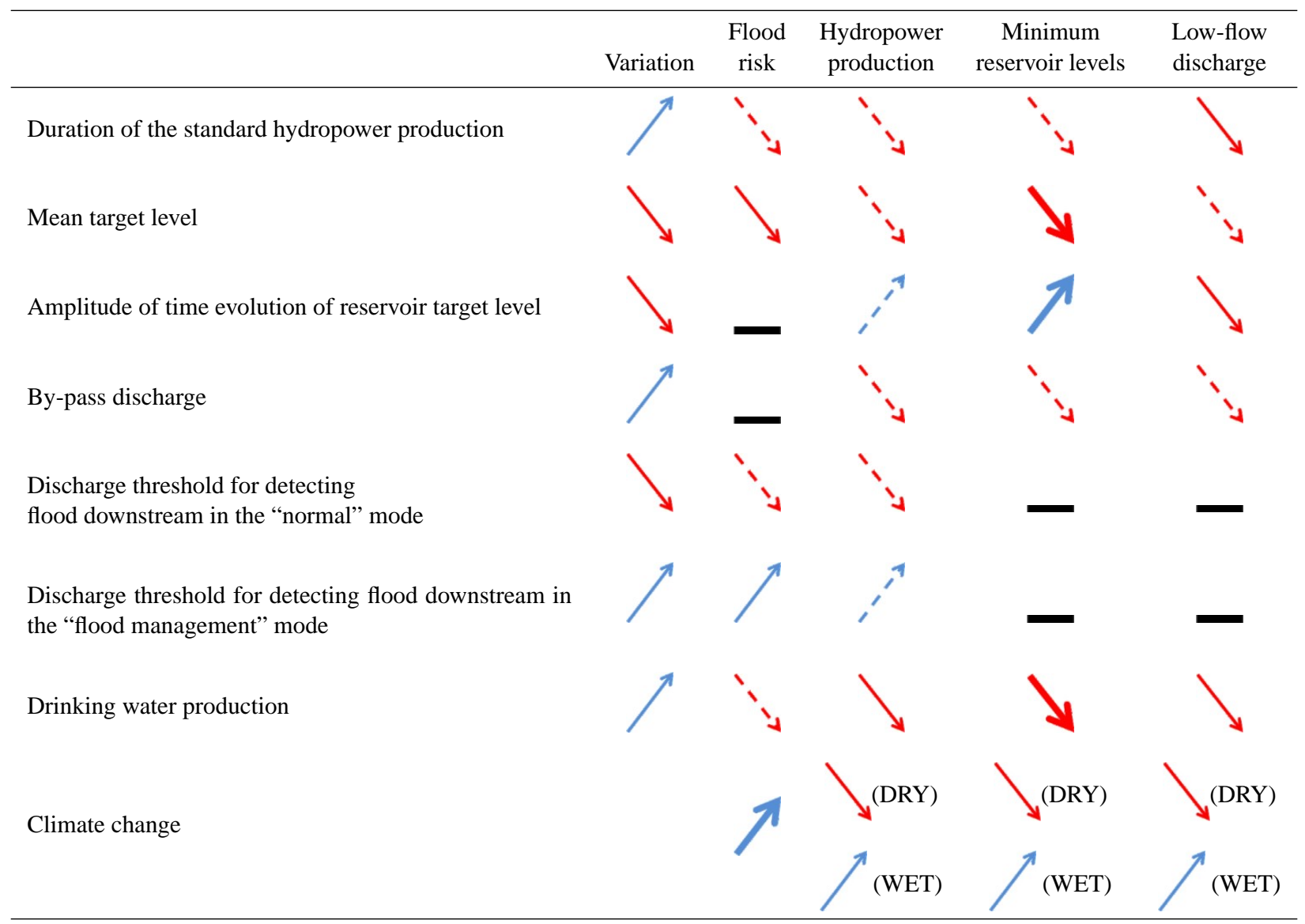

The increase in water demand induces a significant decrease in the minimum reservoir levels which could be mitigated by a reduction in the amplitude of time evolution of the target level.

To compensate for a future intensification of low-flows due to climate change or to an increase in water demand, the duration of the standard hydropower production may be reduced to better distribute the corresponding releases over the entire year. Next, the by-pass discharge could be significantly increased, inducing a reduction of the reservoirs levels. This reduction could be attenuated by a decrease in the amplitude of the target water levels or by adding a test in the operation rules, informing the operator about the need to augment the Vesdre discharge downstream.

\section{Conclusion}

An integrated model has been set up to evaluate the performance of the current operation rules of two large multi-purpose reservoirs in Belgium. The study covers also prospective analysis, including possible changes in water demand and the influence of modifications of hydrological inflows due to climate change. A comprehensive sensitivity analysis of the reservoirs performance with respect to the main parameters of the operation rules has been conducted. It provides a very valuable insight into possible enhancements of the reservoir operation rules to mitigate the impacts of climate change and a possible increase in water demand. Relevant indicators have been defined to quantify the effects of different reservoir operation policies and of climate change on the performances of the two reservoirs: flood risk, mean hydropower potential, minimum daily reservoir levels and the daily discharge not reached 10 days per year (DCE). Based on a detailed modelling chain, involving hydrological and hydraulic modelling, reservoir operation modelling, inundation modelling and damage estimation, a number of robust conclusions could be drawn. 
The present reservoir operation rules proved to be very efficient for flood control in the present climate. Flood risk remains significant only in the lower reach of the river where less than a quarter of the catchment is regulated by the dams.

The sensitivity analysis conducted for the parameters of the existing operation rules has revealed a high influence of the drinking water production on the stored volume, the hydropower production and the low-flow augmentation. Since future increases in drinking water demand are expected, a better knowledge of water demand scenarios is of very high relevance.

Two climate scenarios have been considered, respectively a dry and a wet scenario, for two time horizons: 2020-2050 and 2070-2100. Although the range of variations of the performance indicators is very wide, flood risk is expected to increase in all cases (by 8 to $200 \%$ in 2070-2100 depending on the climate scenario). A limited decrease in the lowest levels of the reservoirs is expected, despite a significant decrease in the mean reservoir levels during the dry season, thanks to a limitation of hydropower production. Hydropower production is highly influenced by climate change and by the volume used for the production of drinking water and the low-flow support, while the operation rules have less influence. An enhancement of the operation rules enables only a limited reduction in flood risk. Decreasing the mean target reservoir levels enables a decrease in flood risk thanks to an increase in available storage. This leads however to restrictions on drinking water supplies. Complementarily, reducing the amplitudes of the time evolution of these target levels restores more available water for drinking water supply, without hampering flood control. Moreover, the discharge threshold for flood warning at Pepinster has also a high impact on flood risk. Measures may be taken to mitigate the intensification of low-flows, with some side-effects on drinking water supply.

Limitations and perspectives of the present study include the following. The meteorological forecasts introduce uncertainties which were not considered at this stage of the research. Although we used the most advanced tool readily available for impact studies in the Belgian catchment, climate scenarios remain also affected by high uncertainties. Scenarios of future water demand should be further developed. Besides climate change, continuing urbanization is another key factor influencing future flood risk (Thieken et al., 2014), but this aspect was not included in the present study. Among others, Beckers et al. (2013) evaluate the increase in flood damage due to land-use change by 2100 between 540 to $630 \%$ in the wet scenario for the whole Meuse valley in the Walloon Region. More generally, the hydrological coefficients were assumed constant in the long-term simulations, while they should be varied to account for catchment adaptation (e.g. change in vegetation) due to an evolving climate. How to adapt the catchment parameters in the hydrological model remains however an open scientific question (Ehret et al., 2014). As flood risk was expressed in monetary terms, impacts of low-flows on various sectors (industry, energy, navigation) should also be estimated; but this remains so far a topic of intense research (Förster and Lilliestam, 2010; Jonkeren et al., 2014; Middelkoop et al., 2001; van Vliet and Zwolsman, 2008) and, in contrast to flood damage estimation, there is not yet a wide consensus nor a generally accepted approach for quantifying the impacts of low-flows.

At this stage of the research, not enough data are available to monetize the reservoirs performance beyond flood risk and enable an informed search for optimal trade-offs between the different management objectives. However, the modelling results generated in the present research pave the way for a more policy-oriented follow-up which would make such a contribution.

Acknowledgements. The research was funded through the ARC grant for Concerted Research Actions, financed by the WalloniaBrussels Federation.

Edited by: H. Kreibich

Reviewed by: two anonymous referees

\section{References}

Bader, J. C, Lamagat, J. P, and Guiguen, N.: Management of the Manantali Dam on the Senegal River: Quantitative analysis of a conflict of objectives, Hydrolog. Sci. J. 48, 525-538, 2003.

Bauwens, A., Sohier, C., and Degré, A.: Hydrological response to climate change in the Lesse and the Vesdre catchments: contribution of a physically based model (Wallonia, Belgium), Hydrol. Earth Syst. Sci., 15, 1745-1756, doi:10.5194/hess-15-17452011, 2011

Beckers, A., Dewals, B., Erpicum, S., Dujardin, S., Detrembleur, S., Teller, J., Pirotton, M., and Archambeau, P.: Contribution of land use changes to future flood damage along the river Meuse in the Walloon region, Nat. Hazards Earth Syst. Sci., 13, 2301-2318, doi:10.5194/nhess-13-2301-2013, 2013.

Bieri, M. and Schleiss, A. J.: Analysis of flood-reduction capacity of hydropower schemes in an Alpine catchment area by semidistributed conceptual modelling, J. Flood Risk Manage., 6, 169$185,2013$.

Bieri, M., Schleiss, A. J., Jordan, F., Fankhauser, A. U., and Ursin, M. H.: Flood retention in alpine catchments equipped with complex hydropower schemes - A case study of the upper Aare catchment in Switzerland, in: Dams and Reservoirs under changing Challenges, edited by: Schleiss, A. J., and Boes, R. M., Taylor and Francis, Lucerne, Switzerland, 387-394, 2011.

Camnasio, E. and Becciu, G.: Evaluation of the Feasibility of Irrigation Storage in a Flood Detention Pond in an Agricultural Catchment in Northern Italy, Water Resour. Manage., 25, 1489-1508, 2011.

Camnasio, E., Erpicum, S., Orsi, E., Pirotton, M., Schleiss, A. J., and Dewals, B. J.: Coupling between flow and sediment deposition in rectangular shallow reservoirs, J. Hydraul. Res., 51, 535547, 2013. 
Castelletti, A., Pianosi, F., and Soncini-Sessa, R.: Water reservoir control under economic, social and environmental constraints, Automatica, 44, 1595-1607, 2008.

Dewals, B. J., Kantoush, S. A., Erpicum, S., Pirotton, M., and Schleiss, A. J.: Experimental and numerical analysis of flow instabilities in rectangular shallow basins, Environ. Fluid Mech., 8, 31-54, 2008.

Dewals, B. J., Erpicum, S., Detrembleur, S., Archambeau, P., and Pirotton, M.: Failure of dams arranged in series or in complex, Nat. Hazards, 56, 917-939, 2011.

Dewals, B. J., Archambeau, P., Duy, B. K., Erpicum, S., and Pirotton, M.: Semi-explicit modelling of watersheds with urban drainage systems, Eng. Appl. Comput. Fluid Mech., 6, 46-57, 2012.

Dewals, B. J., Drogue, G., Erpicum, S., Pirotton, M., and Archambeau, P.: Impact of climate change on inundation hazard along the river Meuse, in: Transboundary Water Management in a changing climate, edited by: Dewals, B. J. and Fournier, M., CRC Press, 19-27, 2013.

Ehret, U., Gupta, H. V., Sivapalan, M., Weijs, S. V., Schymanski, S. J., Blöschl, G., Gelfan, A. N., Harman, C., Kleidon, A., Bogaard, T. A., Wang, D., Wagener, T., Scherer, U., Zehe, E., Bierkens, M. F. P., Di Baldassarre, G., Parajka, J., van Beek, L. P. H., van Griensven, A., Westhoff, M. C., and Winsemius, H. C.: Advancing catchment hydrology to deal with predictions under change, Hydrol. Earth Syst. Sci., 18, 649-671, doi:10.5194/hess-18-6492014, 2014.

Ernst, J., Dewals, B. J., Detrembleur, S., Archambeau, P., Erpicum, S., and Pirotton, M.: Micro-scale flood risk analysis based on detailed 2-D hydraulic modelling and high resolution geographic data, Nat. Hazards, 55, 181-209, 2010.

Erpicum, S., Meile, T., Dewals, B. J., Pirotton, M., and Schleiss, A. J.: 2-D numerical flow modeling in a macro-rough channel, Int. J. Numer. Meth. Fl., 61, 1227-1246, 2009.

Erpicum, S., Dewals, B. J., Archambeau, P., Detrembleur, S., and Pirotton, M.: Detailed inundation modelling using high resolution DEMs, Eng. Appl. Comput. Fluid Mech., 4, 196-208, 2010a.

Erpicum, S., Dewals, B. J., Archambeau, P., and Pirotton, M.: Dambreak flow computation based on an efficient flux-vector splitting, J. Comput. Appl. Math., 234, 2143-2151. 2010 b.

Förster, H. and Lilliestam, J.: Modeling thermoelectric power generation in view of climate change, Reg. Environ. Change, 10, 327-338, 2010.

Fortin, L. G., Turcotte, R., Pugin, S., Cyr, J. F., and Picard, F.: Impact of climate changes on the management plans for SaintFrancois and Aylmer lakes in the south of Quebec, Can. J. Civil Eng., 34, 934-945, 2007.

Heller, P., Bollaert, E. F. R., and Schleiss, A. J.: Comprehensive system analysis of a multipurpose run-of-river power plant with holistic qualitative assessment, Int. J. River Basin Manage., 8, 295-304, 2010.

Hill, M. C. and Tiedeman, C. R.: Effective Groundwater Model Calibration: With Analysis of Data, Sensitivities, Predictions, and Uncertainty, John Wiley \& Sons, New York, USA, 2007.

IPCC Climate Change 2007: Synthesis Report, Contribution of Working Groups I, II, and III to the Fourth Assessment Report of the Intergovernmental Panel on Climate Change, Geneva, Switzerland, 2007.
Jonkeren, O., Rietveld, P., van Ommeren, J., and te Linde, A.: Climate change and economic consequences for inland waterway transport in Europe, Reg. Environ. Change, 14, 953-965, 2014.

Jordan, F. M., Boillat, J. L., and Schleiss, A. J.: Optimization of the flood protection effect of a hydropower multi-reservoir system, Int. J. River Basin Manage., 10, 65-72, 2012.

Kaplan, S. and Garrick, B. J.: On the quantitative definition of risk, Risk Anal., 1, 11-27, 1981.

Kerger, F., Archambeau, P., Erpicum, S., Dewals, B. J., Pirotton, M.: An exact Riemann solver and a Godunov scheme for simulating highly transient mixed flows, J. Comput. Appl. Math. 235, 20302040, 2011a.

Kerger, F., Archambeau, P., Erpicum, S., Dewals, B. J., Pirotton, M.: A fast universal solver for 1-D continuous and discontinuous steady flows in rivers and pipes, Int. J. Numer. Meth. Fl., 66, 3848, 2011 b.

Kerger, F., Erpicum, S., Dewals, B. J., Archambeau, P., Pirotton, M.: 1-D unified mathematical model for environmental flow applied to steady aerated mixed flows, Adv Eng Softw., 42, 660-670, 2011c.

Khuat Duy, B., Archambeau, P., Dewals, B. J., Erpicum, S., and Pirotton, M.: River modeling and flood mitigation in a Belgian catchment, Proceedings of the Institution of Civil Engineers Water Management, 163, 417-423, 2010.

Kreibich, H., Seifert, I., Merz, B., Thieken, A. H.: Development of FLEMOcs - a new model for the estimation of flood losses in the commercial sector, Hydrolog. Sci. J. 55, 1302-1314, 2010.

Magermans, P., Everbecq, E., Bourouag, T., and Deliège, J.-F.: Simulation du bassin de la Vesdre avec le modèle intégré Mohican, AMICE - technical report, Aquapôle, Liege, 2011.

Merz, B., Hall, J., Disse, M., and Schumann, A.: Fluvial flood risk management in a changing world, Nat. Hazards Earth Syst. Sci., 10, 509-527, doi:10.5194/nhess-10-509-2010, 2010 a.

Merz, B., Kreibich, H., Schwarze, R., and Thieken, A.: Review article "Assessment of economic flood damage", Nat. Hazards Earth Syst. Sci., 10, 1697-1724, doi:10.5194/nhess-10-16972010, 2010b.

Middelkoop, H., Daamen, K., Gellens, D., Grabs, W., Kwadijk, J., Lang, H., Parmet, B., Schädler, B., Schella, J., and Wilke, K.: Impact of climate change on hydrological regimes and water resources management in the Rhine basin, Clim. Change, 49, 105128, 2001.

Ntegeka, V., Baguis, P., Roulin, E., and Willems, P.: Developing tailored climate change scenarios for hydrological impact assessments, J. Hydrol., 508, 307-321, 2014.

Payne, J. T., Wood, A. W., Hamlet, A. F., Palmer, R. N., Lettenmaier, D. P.: Mitigating the effects of climate change on the water resources of the Columbia River Basin, Clim. Change, 62, 233-256, 2004.

Poussin, J. K., Bubeck, P., Aerts, J. C. J. H., and Ward, P. J.: Potential of semi-structural and non-structural adaptation strategies to reduce future flood risk: case study for the Meuse, Nat. Hazards Earth Syst. Sci., 12, 3455-3471, doi:10.5194/nhess-123455-2012, 2012.

Roger, S., Dewals, B. J., Erpicum, S., Schwanenberg, D., Schuttrumpf, H., Kongeter, J., and Pirotton, M.: Experimental and numerical investigations of dike-break induced flows, J. Hydraul. Res., 47, 349-359, 2009. 
Sharpley, A. N. and Williams, J. R.: EPIC - Erosion Productivity Impact Calculator: I. Model documentation, US Dept. Agric. Tech. Bull., 1768, 235 pp., 1990.

Sinaba, B., Döring, R., Kufeld, M., Schüttrumpf, H., Bauwens, A.: Impacts of future floods and low flows on the economy in the Meuse basin, Transboundary Water Management in a Changing Climate - Proceedings of the AMICE Final Conference, Sedan, France, 13-15 March 2013.

Sohier, C. and Degré, A.: Modelling the effects of the current policy measures in agriculture: An unique model from field to regional scale in Walloon region of Belgium, Environ. Sci. Policy, 13, 754-765, 2010.

Sohier, C., Degré, A., and Dautrebande, S.: From root zone modelling to regional forecasting of nitrate concentration in recharge flows - The case of the Walloon Region (Belgium), J. Hydrol., $369,350-359,2009$.

SPW: Note de manutention des eaux des barrages de la Vesdre et de la Gileppe, Technical note, 2008 (in French).

Thieken, A. H., Olschewski, A., Kreibich, H., Kobsch, S., and Merz, B.: Development and evaluation of FLEMOps - A new Flood Loss Estimation MOdel for the private sector, WIT Trans. Ecol. Environ., 118, 315-324, 2008.
Thieken, A. H., Cammerer, H., Dobler, C., Lammel, J., and Schöbert, F.: Estimating changes in flood risks and benefits of non-structural adaptation strategies - a case study from Tyrol, Austria Mitigation and Adaptation Strategies for Global Change (2014-10-31), 1-34, 2014.

van Vliet, M. T. H. and Zwolsman, J. J. G.: Impact of summer droughts on the water quality of the Meuse river, J. Hydrol., 353 , 1-17, 2008.

Vorogushyn, S., Lindenschmidt, K. E., Kreibich, H., Apel, H., and Merz, B.: Analysis of a detention basin impact on dike failure probabilities and flood risk for a channel-dike-floodplain system along the river Elbe, Germany, J. Hydrol., 436-437, 120-131, 2012.

Wildemeersch, S., Goderniaux, P., Orban, P., Brouyère, S., and Dassargues, A.: Assessing the effects of spatial discretization on large-scale flow model performance and prediction uncertainty, J. Hydrol., 510, 10-25, 2014.

Williams, J. R., Jones, C. A., and Dyke, P. T.: A modelling approach to determining the relationship between erosion and soil productivity, Trans. Am. Soc. Agr. Eng., 27, 129-144, 1984. 